\title{
Educational Board Game Development to Increase the Knowledge of Local Wisdom
}

\author{
Yossa Istiadi*, Rita Istiana, Indra Nusantoro Hatasura \\ Environmental Management \\ Pakuan University \\ Bogor, Indonesia \\ *yossaistiadi@unpak.ac.id
}

\begin{abstract}
The purpose of this research is to develop educational board games as well as learning initiatives in the environmental education approach. The research and development approach is used to be applied in the Kasepuhan traditional community around the Mount Halimun Salak National Park, West Java from January to April 2019. The method phase went through a needs assessment, validation, and recommendation phase. Board games consist of paper boards by drawing content knowledge as well as some character drawings that illustrate the philosophies, values, norms, behavior, roles, institutions, regions, and environment in their communities. Each board game can be played by 4 students with duration of 1-3 hours also using a discussion card. Based on the validation phase with a three-cycle test $(n=24$ samples and analyzed by $t$-test $)$, there is a significant difference in knowledge about local wisdom between cycle 1 and cycle 2 (t test $=2,863 ; n=24 ; p<0,01$ ), and between cycle 2 and cycle 3 ( $t$ test $=2.96 ; n=24 ; p<0.01$ ). It was stated that this method showed a better knowledge of local wisdom with board repair games each cycle.
\end{abstract}

Keywords: educational board game, local's wisdom, traditional community

\section{INTRODUCTION}

The implementation of the national curriculum can foster nationality in human resources. However, this application tends to dilute local content that arises from original knowledge. The impact of depletion can reduce local uniqueness as a result of global and national pressure on their development [1,2]

Indonesia consists of thousands of local wealth so that its opportunities grow from empowerment of local superior. In addition, the national curriculum has not yet reached the specific content of local knowledge. At present, existing tribes have problems with their belief in values, norms, culture, life activities, organization and land ownership. Some of them cause local knowledge to have obstacles to produce for the youngest people. Somehow, the role of the national curriculum must provide opportunities for learning traditional customs $[3,4]$.

Educational board games where recognition of local knowledge might lead to complement learning activities. The concept of the game is built based on cooperative learning, problem-based learning, participatory learning models, and portable learning tools [5]. Board games are traditional learning tools that are included in role playing. In Indonesia, the board game appeared before the game of ladder snake, chess, monopoly, othello, ludo, and others. The characteristics of board games are characterized by learning tools with physical boards, played with competitiveness or collaboration, the story and purpose of the game, and its accessories. In general, board games can be played by two or more players.

In mentioning gamification as a board game, learning trends in game models are made for the enrichment and feedback of knowledge in empowering local wisdom in their tribes. Meanwhile, it will be used for decision making principles in the preservation of natural resources [6,7].

The research problems that will be revealed are (1) Can the local wisdom of board games increase about traditional customs? (2) How can the application of board games be effective to improve traditional customs?

\section{METHODS}

This study uses a Research and Development (RnD) approach [8]. The study was conducted thoroughly during the January-June 2019 period in the Kasepuhan Banten Kidul tribe community separately around the Mount Halimun Salak National Park, Banten Province. The research phase was 6 phases consisting of (1) needs assessment, (2) information gathering, (3) planning, (4) development of the Draft model (5), validation phase with increasing cycles, and (6) recommendations. Data analysis included descriptive analysis in designing the board game model, while inferential analytics included a t test between the validation cycles.

\section{RESULTS AND DISCUSSION}

\section{A. Develoing Board Game}

Our descriptive survey emphasizes the role of the learning model as an extra activity in school. The survey with interviews with teachers, stakeholders, parents in 4 villages such as Ciptarasa, Pagelaran, Malasari, and Urug illustrates that $72 \%$ support for this type of learning with pleasure, dynamics, groups, emotions and stimuli, and by developing learning tools. 
About $15 \%$ support for learning by parents, and 10\% support for formal learning in class. While 3\% did not answer. These results have in common when the survey was conducted on students.

Some theoretical and information gathering shows that the Dale Cone experience fits the mechanism of dynamically conveying knowledge and attracts students through visual stimulation and interactive play as a simulation of experience. In developing the learning design as a model, board games have been created that have content about the role of customary life in accordance with the flow of the game that the game is played by 4 individual players or groups. The role playing component consists of (1) character choices, (2) starting to play by throwing "Dice", (3) being cooperative in groups to defeat your opponents, and (4) total player scores (Figure 1). This type of game is an attempt to eliminate enemy bosses where the player must cooperate with all players. Scoring each player can be calculated based on knowledge points + gold points + equipment prices + (boss attack rate $\mathrm{x} 2$ ).

Some content related to playing games such as natural resources is biodiversity as part of the game flow (Figure 2). Meanwhile, other comments need to get the recognition of the Indigenous Kasepuhan (Figure 3).

Model validation is to apply the game and analyze and improve with three cycles. Each cycle may take 2 to 3 hours and continue to reflect on parties such as observers, researchers, teachers, and students. The first cycle was collected from the village of Ciptarasa with a sampling of 24 players which showed that the average score was around 73.83 where the lowest score was 62 and the highest score was 91 or a gap score of 29. According to reflection found some improvements especially regarding the size of board games, content knowledge, students involved, and the role of players.

The second cycle is applied after three weeks from the first cycle in Urug village. The results of these games show, the average score is 80.86 where the lowest score is 68 and the highest score is 98 or the gap score is 30 . Developing the game board in this cycle reveals that the increase in score while the gap score looks bigger. In this case, some improvements from the board game focused on the role of group players.

Through the $t$ test, local wisdom knowledge between cycle 1 and cycle 2 shows $t=2.863(p<0.01)$, which means there is a very significant difference (Ho is rejected) which has an effect between treatment 1 and treatment 2 .

The third cycle on Village Performance which was applied after 3 weeks showed that the average score increased to 88.5 where the lowest score was 62 and the highest score was 105 , then the gap score range was around 47 . The gap score in this third cycle can be said that the goal from board games have optimized their local wisdom knowledge such as Kasepuhan Banten Kidul.

Through the $\mathrm{t}$ test of local wisdom knowledge between cycle 2 and cycle 3 can be explained $t=2.96$ ( $p<0.01)$, there is a very significant difference (rejected $\mathrm{Ho}$ ) which has an influence between treatment 2 and treatment 3 .

\section{B. Validation Phase}

Model validation is to apply the game, analyze it and improve with three cycles. Each cycle may need 2 to 3 hours and continued with reflection between parties such as observers, researchers, teachers, and students. The first cycle was collected in Ciptarasa village with a sample of 24 players which showed an average score of around 73.83 (lowest score 62; highest score 91). Reflection results show some improvements, especially regarding board size, knowledge content, students involved, and the role of players.

The second cycle is applied after three weeks from the first cycle in Urug village. The results of the game showed an average score of 80.86 (lowest score 68; highest score 98). In this case, some improvements to the focused board game lie in the role of group players.

Through the $\mathrm{t}$ test, knowledge of local wisdom between cycle 1 and cycle 2 can be explained $t=2.863(\mathrm{p}<0.01)$, where there is a very significant difference (Ho is rejected) that affects between treatment 1 and treatment 2 .

The third cycle in the village of Pagelaran where applied after 3 weeks showed that the average score increased to 88.5 (lowest score 62; highest score 105), then the gap score range was around 47 . The gap score in the third cycle can be said that achieving the goal from board game has optimized their knowledge of local wisdom such as Kasepuhan Banten Kidul.

Through the $t$ test of local wisdom knowledge between cycle 2 and cycle 3 can be explained $t=2.96(p<0.01)$, there is a very significant difference (Ho rejected) that affects between treatment 2 and treatment 3 .

\section{Discussion}

Gamification in education is also a board game approach intended for knowledge acquisition. Gamification is based on the use of game-based mechanics, aesthetics, and game thinking to engage people, motivate, promote learning, and solve problems. Game-based mechanics includes how to play, aesthetics including drawing, painting, sketching, and thinking games including content that is realized [9-11].

We observe and document the behavior of the players. They first formed a team with up to four individuals as a group.

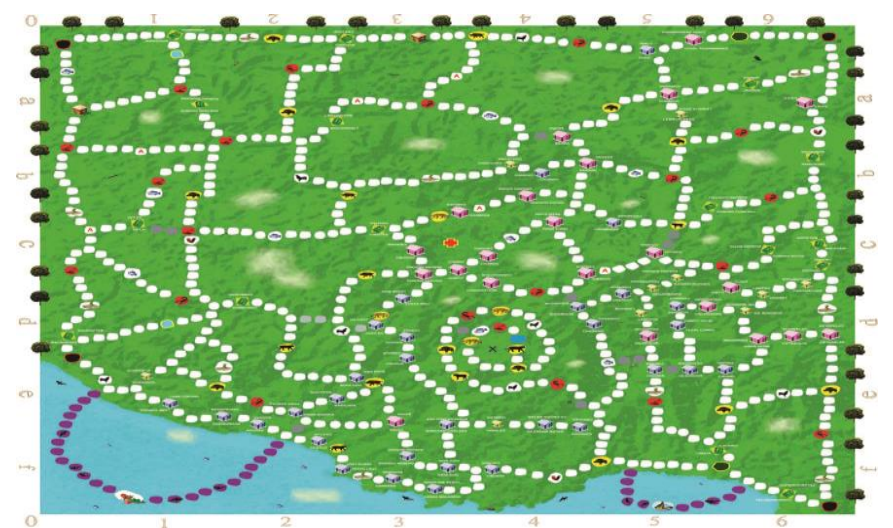

Fig. 1. Traditional wisdom model draft board game. 


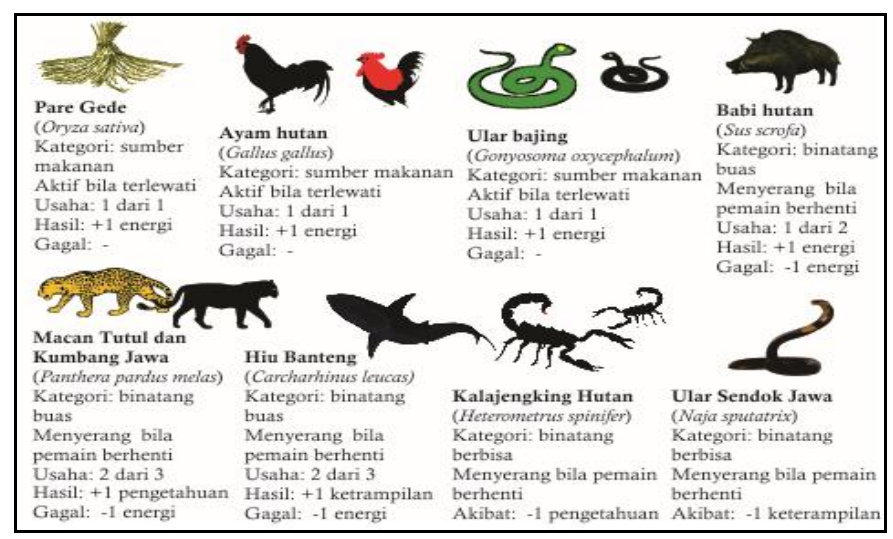

Fig. 2. Object card 1.

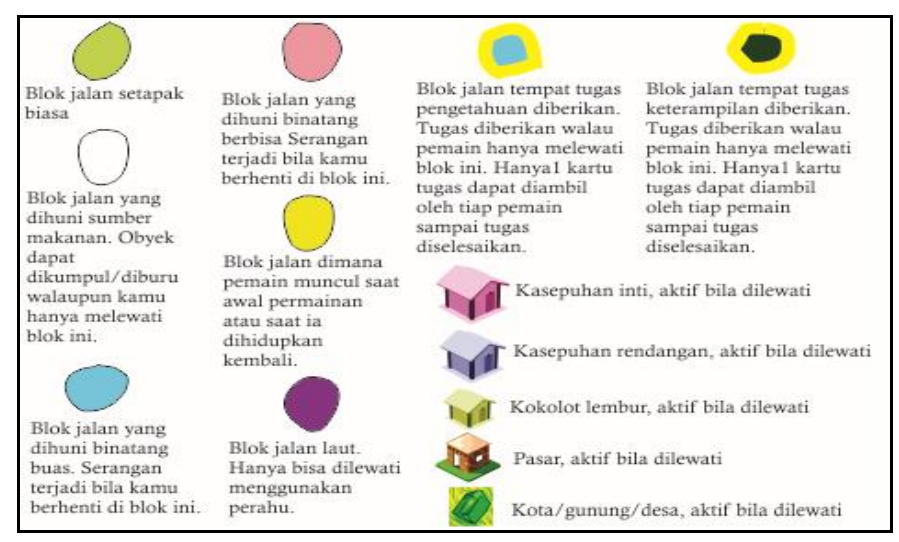

Fig. 3. Object card 2.

All teams strangely followed the game with instructions and issued components. This is a good proof of the flexibility of the concept, leaving the player to set the game alone and thus fulfill the rules of independent learning. Some teams read the instructions before starting, while others do it step by step. However, there are no questions about how to manage the game or about the rules, what proves that these aspects are easy to understand. They concluded that effectively designed games can stimulate large increases in productivity and creativity among students. Playing time per domain mainly depends on the number of questions and players. To avoid excess students, ten questions are considered reasonable. With this number four people playing four domain boards takes about 70 minutes. Using various types of questions is another way to achieve variation from a player's perspective.

Implementing games with a web-based approach will be difficult in tribal communities. The design of gamification in web and mobile applications has various difficulties in areas where the internet exits [12-14]. All these results clearly show that the game to a high degree meets the requirements. From a student's perspective it promises fun and pleasure, encourages independent learning where students can decide what and how much to learn in what order and in which detail and thus have a high motivational effect. The answer also points to fulfilling the teacher's requirements for transporting 'boring' learning content with fun without a complete explanation of the game.
Game mechanics are a means of applying motivational values. They aim for psychological outcomes such as motivation, pleasure and attitude, which in turn can lead to changes in behavior such as preparing tasks or working together in teams. Thus the game mechanic stimulates people to participate and enjoy the game. They facilitate and encourage users to explore and learn the properties of their possible spaces through the use of feedback mechanisms [15].

We also pay attention to the various handling of the question inquiries card. In some teams, a question is raised loudly by other players. Meanwhile, other groups prefer to read it themselves by the players. The subject of questions is often discussed and explained in teams.

\section{CONCLUSION}

We follow the gamification approach to developing board games as an instrument for teacher's didactic toolboxes that can be chosen from when applying mixed learning concepts including interactive and self-learning elements.

First, the "Local wisdom" board game can influence the increase of their tribal knowledge and continue as an extra didactic curator toolbox.

Second, the feedback we have collected shows that the game is suitable for handling the requirements identified for intended use. First of all, students and teachers confirm the effects of increasing motivation to learn and enjoyment in the context of the content contained in the theory. The limits of positive effects can be assumed for the repeated use of game concepts for different learning content with the same group of students in a short amount of time. Extensions and variations can help avoid or at least reduce these limits. This also includes trying and analyzing the effects of variations with several control groups, including students and teachers. This finding can serve as a trigger to adapt game design.

\section{REFERENCES}

[1] W.R. Penuel, B.J. Fishman, R. Yamaguchi, L.P. Gallagher, "What makes professional development effective? Strategies that foster curriculum implementation," American educational research journal. Vol. 44, no. 4, pp. 921-58, 2007.

[2] I. Meliono, Understanding the Nusantara thought and local wisdom as an aspect of the Indonesian education. TAWARIKH. 2011, vol. 2, no. 2.

[3] N.N. Selasih, I.K. Sudarsana, "Education Based on Ethnopedagogy in Maintaining and Conserving the Local Wisdom: A Literature Study," Jurnal Ilmiah Peuradeun, vol. 6, no. 2, pp. 293-306, 2018.

[4] A. Siswanto, A.S. Salim, N.D. Dahlan, A. Hariza, "The Phenomenology of Lamban Tuha: The Local Wisdom of South Sumatra Traditional Architecture," International Transaction Journal of Engineering, Management, \& Applied Sciences \& Technologies, vol. 4, no. 2, pp. 157-70, 2013.

[5] B. Bontchev, D. Vassileva, "Educational quiz board games for adaptive e-learning," InProc. of Int. Conf. ICTE, pp. 63-70, 2010.

[6] D. Dicheva, C. Dichev, G. Agre, G. Angelova, "Gamification in education: A systematic mapping study," Journal of Educational Technology \& Society, vol. 18, no. 3, 2015. 
[7] G. Kiryakova, N. Angelova, L. Yordanova, "Gamification in education", Proceedings of 9th International Balkan Education and Science Conference, 2014.

[8] S. Jufri, G.H. Sulistyo and S. Rachmajanti. Developing Multimedia Board Games As Media To Learn English Vocabulary For Young Learners, Jurnal Pendidikan: Teori, Penelitian, dan Pengembangan, vol. 1, no. 1, pp. 15-28, 2016.

[9] K.M. Kapp, The gamification of learning and instruction: game-based methods and strategies for training and education. John Wiley \& Sons; 2012.

[10] B. Taspinar, W. Schmidt and H. Schuhbauer, "Gamification in education: a board game approach to knowledge acquisition," Procedia Computer Science, vol. 99, pp. 101-16, 2016.

[11] P. Buckley and E. Doyle, "Gamification and student motivation," Interactive learning environments, vol. 24, no. 6, pp. 1162-75, 2016.
[12] I.G. Martí, L.E. Rodríguez, M. Benedito, S. Trilles, A. Beltrán, L. Díaz and J. Huerta, "Mobile application for noise pollution monitoring through gamification techniques," InInternational Conference on Entertainment Computing, pp. 562-571, 2012.

[13] G. Zichermann and C. Cunningham, Gamification by design: Implementing game mechanics in web and mobile apps. "O'Reilly Media, Inc.", 2011.

[14] F. Khaddage and C. Lattemann, "towards mobilizing mathematics via gamification and mobile applications," Mobile Learning and STEM: Case Studies in Practice, 263, 2016.

[15] R. Hervas, D. Ruiz-Carrasco, T. Mondejar and J. Bravo, "Gamification mechanics for behavioral change: a systematic review and proposed taxonomy," InProceedings of the 11th EAI International Conference on Pervasive Computing Technologies for Healthcare, 395-404, 2017. 